\title{
The Research of Management Mode Innovation for Army Professional Education College Scientific Research Management
}

\author{
Yi Jin ${ }^{1, a}$, Xue Wang ${ }^{2, b}$ and Di Wang ${ }^{3, c}$ \\ ${ }^{1,2,3}$ Changchun engineering technology college, Changchun, 130117, China \\ a,b,c email: 15344554820@163.com
}

\begin{abstract}
Keywords: Army Professional Education College;Scientific research;Management mode; Innovation
\end{abstract}

\begin{abstract}
With the rapid development of the army education and scientific research status of the army colleges and universities are increasingly valued. Research to the office of education teaching and personnel training and military service functions better play a very important role. But because the army colleges and universities and scientific research started relatively late, in terms of its scientific management mode, there are some shortcomings. Restricted the army colleges and universities of science and technology innovation and the cultivation of applicable talents. Combining with the army education university stage of development, and the characteristics of the actual, put forward the corresponding scientific research management mode of building strategy.
\end{abstract}

\section{Introduction}

Scientific research of the army of the education teaching, personnel training, and forces the service function of good play a very important role. The level of scientific research is the embodiment of the colleges and universities competitive ability. Scientific research and the scientific research level has become a measure of the army education institutions and their faculty is a sign of maturity. Look from the current situation, some has expanded scale, relatively stable army are the research xingjiao, strong scientific research education colleges as an important task to grasp, and has obtained the remarkable effect. Even so, many people believe that the army talent less education colleges, foundation is poor, money is not enough, should not carry out the scientific research work, should focus on teaching and service[1]. This is the relationship between scientific research and teaching and scientific research and serving the army can not correctly understand the performance. Scientific research can effectively promote the teaching reform, teaching and personnel training quality enhances unceasingly. Scientific research and teaching, scientific research and talent cultivation is promote each other relations, we can't take the army scientific research and teaching reform, skills, talents cultivation separating them. Scientific research support and service of colleges and universities teaching and personnel training work, is the value of the colleges and universities and scientific research of specific goals. In addition, only do a good job in the scientific research work, the army education colleges have forces need to patents and technology, in order to better serve the troops. The scientific research work of the army education colleges and universities to promote the teaching reform, improve students' ability of the position, services and so on many aspects has a very positive role.

\section{The management mode of scientific research}

Long-term since, our country the army education colleges and universities and education institutions, except there is difference on talent cultivation of the talent cultivation model, specialty setting, curriculum has great similarity. The army with record of formal schooling education colleges and universities only on the system have the difference. Many the army education colleges and universities can't correct understanding to the research for the army education colleges unique meaning and value, can not correctly design conforms to the scientific research management mode. Defects of existing pattern is mainly manifested in the following aspects: 


\subsection{Scientific research work in the position of the marginalized}

Scientific research work in the army in a marginal position in the education colleges and universities. Should give way to other work in the work schedule, don't be incorporated in the work schedule. Some army education colleges and universities scientific research management departments and part of the faculty think scientific research for the army education colleges is dispensable, ignore the function of scientific research for the promotion of other functions, dissever the relationship between scientific research and teaching, and neglected the research on faculty and the student beginning ability, ability and innovative ability of exercise.

\subsection{In terms of scientific research topic selection guide is not accurate}

Some don't go to guide teachers engaged in scientific research management department has a comparative advantage of teaching research and technology promotion projects, but to research vertical subject blindly, not as a result, the effect not beautiful. And most of the army education colleges and universities due to reasons such as performance evaluation of scientific research ideas and guidance, think the longitudinal research is scientific research, teaching research and horizontal topic not included in the research area.

\subsection{Production-study-research cooperation is not quite close together}

The army education colleges and universities still follow "to declare a project study appraisal one win" the old model, the theoretical value of the one-sided pursuit of achievements, did not establish effective production mode. For scientific research management department in achievements link responsibility and obligation is not yet clear, application achievements of relevant systems and regulations has not been established and achievements transformation of incentives does not reach the designated position. Eventually lead to cannot be effectively realizes the achievements and the development and application.

\subsection{Not enough support for scientific research work of other departments}

Some army education of colleges and universities libraries, archives, journals of colleges and universities, financial department, practice bases and other departments, there are a lot of think scientific research should be provided by the scientific research department to service, has nothing to do with himself, in the absence of the scientific research activities.

\subsection{Scientific research management personnel service consciousness}

At present, many army education of colleges and universities scientific research management team personnel shortage, management ability, communication skills and decision-making ability is not strong. Management guiding ideology and management level is not high, do not understand the academic norms, is not familiar with on science and technology policy, not understanding the scientific research strengths and characteristics of the colleges and universities, don't pay attention to scientific research hot spot[2].

\section{The construction of a new scientific research service pattern strategy}

\subsection{Form the unique characteristics of the colleges scientific research service mode}

The army education colleges and universities should follow the general law of education development, learning developed countries experience in train applied and technical persons, out of a capable the position and the characteristics of practice of running a school. To this end, the army in colleges of education orientation, personnel training target, training mode, the scientific research service to different $\mathrm{Yu}$ Xueli education colleges and universities. The army education colleges and universities only on the characteristics, to better service units. The army scientific research of education colleges should also form characteristic, only to form the characteristic, can better to form the core ability of the colleges and universities. Schools should be based on the analysis, the current level of study, according to the technology development, combined with the colleges and universities development goals, identify key areas of research and development. Establish scientific development goal, and actively introduce talents, establish scientific talent echelon, gradually formed its own characteristics of scientific research[3]. The army of education colleges and scientific research of cannot blindly 
follow or mechanical follow the standard of education colleges, want to combine their own school-running orientation. Not good 'far, want to combine the actual scientific research ability of faculty, in line with "conform to the objective, reasonable positioning, and highlight the characteristic" principle, to encourage faculty to enhance scientific research consciousness, actively carry out scientific research work, improve the balance of the teaching and scientific research.

\subsection{Improve scientific research management system}

Institutional environment is often from a deeper influence on management object and social activities. The army education colleges and universities must strengthen scientific research management system management consciousness. The army education colleges and universities scientific research management departments should as far as possible for the majority of researchers from on macroscopic to create a good institutional environment. According to the needs of different stages of scientific research work, establish the reasonable incentive factors, cultivate the spirit of collaboration between different disciplines and professional, to promote and strengthen the institutions of professional integration. For integration of scientific research personnel to carry out the interdisciplinary research, collaborative research, the efficient conversion of research to create the conditions of the system.

First of all, be clear what behavior is not in conformity with the academic standard, what is a breach of academic morality. In writing, signed, lead Note, published, publicity, awards, etc., for academic corruption, academic misconduct and academic wrongdoing to explicitly banned, according to the different person, different situations (such as bribery and plagiarism, false references, not objective evaluation and fake data, etc.) to give criticized academic position, cancellation or disqualified from visiting, vacation, declare project, etc.

\subsection{Making scientific research management operation mechanism}

\subsubsection{Build open active scientific research management operation mechanism}

Project requirements, fruit generation and transformation of docking together form a new mode of scientific research management operation of the three main node. Which occupies primacy subject requirements, is the premise of scientific research generated with the successful transformation. Results generated is asked link, both restrict the subject demand, also restricts the conversion of docking. Docking is research achievements into realistic productivity transformation "interface", determines the size of the investment effect. If high achievements conversion rate will stimulate demand growth, prompted more achievements, to produce good results.

\subsubsection{The scientific research management system of flattening}

The army education of colleges and universities scientific research management organization flattening refers to reform the traditional vertical management organization system. Reduce the middle level organization, makes the basic scientific research personnel with sufficient information right to know and discretion, independently in horizontal coordination, sharing knowledge and information freely. Senior policymakers focus on the scientific research organization's strategic management, and other non programmed decisions, and communication of each transverse scientific research management organization pattern. This system is to establish scientific research personnel to fast access to scientific information, can be the fastest to realize information exchange, easy to realize knowledge sharing, to a great extent improve scientific research results.

\subsection{To improve scientific research management}

Scientific research management informationization is a systematic project, need many efforts. Establish college scientific research management network platform, promote the scientific research management scientific and standardized. The use of advanced information technology support for scientific research management. The dissemination of scientific information, using computer network technology for scientific research information release, the achievements of scientific research project management, project funds management, incentive, the application and scientific research evaluation and scientific research statistics of network operation and management activities such as the paperless office. And combined with modern scientific management ideas and effectively[4].The actual 
situation of college scientific research management, and promote the scientific research management scientific and modernized.

\subsection{Build a performance evaluation system of scientific research}

Scientific research evaluation should not only evaluate the individual researchers, and want to colleges and universities to evaluate scientific research plan, research projects and research team. Assessment involves not only the content of the research activities of product directly, and attaches great importance to the scientific research of various effects, attaches great importance to the scientific research of the diversity of output and its contribution to the force. The working process of the emphasis on scientific research and comprehensive evaluation of long-term effect. By establishing a diversified performance evaluation system, comprehensive, objective, huai accurately reflect the scientific research personnel and research institutions of scientific research and practical results. The research institutions and researchers target management, clear goals and tasks of jobs and annual plan task. Suggestions to strengthen the scientific research performance evaluation, therefore, should pay attention to in the assessment through various channels to ensure evaluation in assessing the independence of the behavior, set up open performance evaluation mechanism, to ensure transparency of the assessment. To make full use of the results of performance evaluation at the same time, in order to achieve evaluation purpose, mobilizing the scientific research enthusiasm of faculty.

\subsection{Strengthen the scientific research management ability}

Scientific research management personnel management skills including strong judgment ability, independent working ability, organization ability, communication ability of different composition. Scientific research management personnel should not only learn management theory and management theory to guide the actual work, and to summarize in the rich practice experience. To deal with a large amount of data, information, must have the information analysis ability, and have to deal with different levels of personnel, have good communication and organization skills. So the scientific research management personnel need to master certain management art and skill, to apply management theory, method and means to work. To work in scientific research management theory as the guidance, on the premise of scientific research and practical guidelines for research and practice. In the reorganization of the work is good at ideas, determine priorities, key points and difficult points. Therefore, the scientific research management staff on the one hand, some scientific management concept to use in the scientific research management; On the other hand, must pay attention to improve their own quality, to adapt to the new situation, the new situation faced in the scientific research management.

\section{Conclusion and prospect}

Scientific research of the army of the education teaching, personnel training, and forces the service function of good play has a very important role. The level of scientific research is a reflection of the army education colleges competition ability. Scientific research and the scientific research level has become a measure of the army education institutions and their faculty is a sign of maturity. Combining with the army education development phase and the actual characteristics of college education, puts forward the new type of scientific research management mode, and build the new strategy, to the army service pattern by the administrative departments of education colleges and scientific research to explore and research is very necessary, has the very important significance.

\section{References}

[1] Yu-lian Jiang. Higher vocational college journal editors and scientific research and teaching of trinity [J]. Nanning vocational and technical college to learn , 2005, 10 (2) : 97-100.

[2] Yi-shao Xu. Study on the analysis of scientific research in higher vocational colleges positioning problem [J]. Higher vocational education: tianjin vocational college Journal, 2009, 8 (2), 1:82-85. 
[3] Shan-qing Zhao. Talk about the scientific use of higher vocational school funding [J]. Business times, 2007 (26) : 74-75.

[4] Jing-hong He. The exploration and practice of higher vocational colleges to build scientific research platform where. Mechanical professional education, 2009 (5) : 36-37 . 